\title{
Od umowy o władzę do nietolerancji religijnej. Samuel Rutherford i kontraktualne uzasadnienie prześladowań religijnych
}

\author{
Władza świecka powinna zgładzić bluźniercę, kazirodcę, \\ cudzołożnika, wiedźmę i im podobnych. \\ George Gillespie, Miscellaneous Questions
}

\section{Wstęp}

Wraz z rozpadem Christianitas Europę ogarnął ideowy ferment, którego nie doznała nigdy wcześniej w swojej historii. Konkurujące wzajemnie wyznania chrześcijańskie toczyły spory, które miały wymiar nie tylko teologiczny, lecz rychło przerodziły się także w konflikt polityczny w postaci wojen religijnych ogarniających Europę. Istotnym jego elementem było określenie, czy w ogóle możliwe jest istnienie kilku wyznań chrześcijańskich w ramach jednej wspólnoty politycznej i ewentualnie według jakich zasad ma być to regulowane. Nie ominęło to również Wysp Brytyjskich, na których wraz z Aktem supremacji Henryka VIII powoli, lecz sukcesywnie narastał spór. Jego kulminacją była rewolta purytańska, toczona przede wszystkim w imię racji religijnych, wspieranych tylko wywiedzionymi z niej argumentami politycznymi i konstytucyjnymi. Jednym z najważniejszych punktów zapalnych była kwestia ustroju Kościoła Anglii, który za czasów Tudorów przybrał formę nieakceptowaną przez znaczną część kalwińskich radykałów, zwłaszcza że Elżbieta I nie cofała się przed najbardziej nawet radykalnymi środkami skierowanymi zarówno przeciw katolikom, jak i nonkonformistom. Nigdzie indziej nie wprowadzono bowiem tak drastycznych kar za wykroczenia religijne, 
zrównując je ze zbrodnią stanu ${ }^{1}$. Stąd naturalnym odruchem ze strony prześladowanych było domaganie się tolerancji, lecz o ile katolicy żądali jedynie prawa do pozostania przy wierze swych ojców, o tyle kalwini interpretowali to pojęcie inaczej, pragnąc de facto dostosowania angielskiego systemu eklezjalnego i teologicznego do ich wymagań. Sytuacja zaogniła się jeszcze bardziej wraz z wstąpieniem na tron angielski Jakuba I (VI), programowo nienawidzącego purytanów po swych przykrych doświadczeniach ze szkockim Kirkiem, a punkt kulminacyjny osiągnęła pod rządami jego syna. W wyniku niepowodzeń w wojnie ze zbuntowaną Szkocją parlament, realizując jeden z postulatów Wielkiej Remonstracji, powołał Westminsterskie Zgromadzenie Świętych, którego celem miało być określenie teologicznego kanonu oraz ustroju eklezjalnego Anglii. Obok delegatów angielskich brało w nim również udział, na mocy Uroczystej Ligii i Przymierza, jedenastu przedstawicieli Szkocji, a wśród nich jeden z najbardziej szanowanych i prominentnych szkockich teologów Samuel Rutherford². Badaczom myśli politycznej jest on, jeśli w ogóle, znany przede wszystkim jako autor traktatu Lex, Rex, będącego istotnym wkładem w rozwój koncepcji umowy społecznej, a zatem koncepcji, która mimochodem dzisiaj kojarzy się z państwem tolerancyjnym i nieopresyjnym. Mimo że książka Rutherforda ma charakter polemiczny i wydaje się jedynie elementem sekciarskich sporów toczonych w tym okresie, to jednak są one jedynie pretekstem do rozwinięcia oryginalnej koncepcji genezy władzy, jej zakresu, granic posłuszeństwa oraz prawa oporu wobec tyranii. $\mathrm{Z}$ tego powodu myśl polityczna Rutherforda zainspirowała między innymi Johna Adamsa, który znajdował się pod wielkim wpływem zawartych w Lex, Rex idei ${ }^{3}$. Jego pomysły uprawomocniające rebelię i przedstawiające ją jako chrześcijański obowiązek dotarły bowiem do Ameryki dzięki prezbiteriańskim kaznodziejom, stając się

1 J. Lecler, Historia tolerancji w wieku reformacji, przeł. L. i H. Kühn, Warszawa 1964, t. 2, s. 324.

2 Samuel Rutherford urodził się około roku 1600 niedaleko Crailing, w południowo-wschodniej Szkocji. W latach 1617-1621 studiował na Uniwersytecie w Edynburgu, gdzie związał się z radykalnymi prezbiterianami sprzeciwiającymi się Pięciu artykułom z Perth. W roku 1627 został pastorem w Anwoth, gdzie prowadził dalszą kampanię przeciwko królewskiej polityce. Z tego powodu został postawiony w stan oskarżenia i umieszczony w areszcie w twierdzy Aberdeen. Rok później, w zmienionej sytuacji politycznej został jednym z animatorów Narodowego Przymierza i główną postacią szkockiego duchowieństwa. W roku 1639 został profesorem teologii w New College na Uniwersytecie St. Andrews - funkcje piastował do roku 1660. W latach 1643-1647 był szkockim delegatem do Westminsterskiego Zgromadzenia Świętych. Po powrocie do Szkocji sprzeciwiał się porozumieniu umiarkowanych Covenanters z Karolem I. Po klęsce pod Dumbar Rutherford, wygłaszając kazania i publikując prace teologiczne, cały czas związany był ze stronnictwem radykalnym. Dlatego po restauracji wydalony został z uniwersytetu i uwięziony w areszcie domowym. Zanim stawił się przed parlamentem, by odpowiedzieć na zarzut zdrady, zmarł 8 marca 1661 roku, Puritans and Puritanism in Europe and America. A Comprehensive Encyclopedia, red. F.J. Bremer, T. Webster, Santa Barbara-Denver-Oxford 2006, s. 222-224.

3 S. Bamberg, A Footnote to the Political Theory of John Adams Vindiciae contra tyrannos, „Premise” 3, 1996, nr 7, s. 8. 
istotnym elementem refleksji kolonistów tak bardzo, że Jerzy III nazwał podobno amerykańską wojnę o niepodległość „rewolucją prezbiteriańską”4 . Czynił tak między innymi zapewne z powodu swej nieznajomości innych traktatów Rutherforda, które każą spojrzeć na niego z zupełnie innej perspektywy. Albowiem jeśli czytać będziemy go razem, dla przykładu, z A Free Disputation, to się okaże, że w istocie argument Rutherforda zmierza do uzasadnienia państwa niebywale opresyjnego w dziedzinie religii. Traktat ten był bowiem odpowiedzią na Liberty of Prophesying Jeremy'ego Taylora, Bloody Tenet Rogera Williama i Hagiomastix and Theomachia Johna Goodwina, w których autorzy domagali się częściowej choć tolerancji religijnej, wyrażając opinię dużej części stronnictwa parlamentarnego $\mathrm{i}$ armii. Tymczasem traktat Rutherforda jest w istocie jedną $\mathrm{z}$ największych, obok Gangraena Thomasa Edwardsa, obroną prześladowań ${ }^{5}$, z których w okresie reformacji słynęła Szkocja, i próbą przeniesienia ich na grunt angielski. Stąd celem niniejszego artykułu będzie wykazanie, że kontraktualne pomysły Rutherforda z jednej strony są orężem wymierzonym przeciwko władzy absolutnej, z drugiej zaś władzę taką usprawiedliwiają, jeśli tylko stosowana jest wobec odstępców od jedynej ,prawdziwej religii” reprezentowanej przez szkockich prezbiterian.

\section{Prawo natury}

Europejska myśl polityczna w okresie średniowiecza, renesansu i wczesnej nowożytności w oczywisty sposób, jako aplikacja teologii, musiała być i była chrześcijańska lub wykazywać istotne chrześcijańskie uwikłanie, nawet tam, gdzie była inspirowana tradycją klasyczną. W wirze religijnego zamieszania, jaki przyniosła reformacja, pytania o prawo i formy życia politycznego były właściwie pytaniem o to, czego życzy sobie Stwórca. Były w istocie pytaniami o właściwe zrozumienie Boskich nakazów przekazanych w Piśmie i Tradycji. Dlatego Rutherford jest bezsprzecznie dzieckiem swoich czasów i okoliczności, w których przyszło mu podjąć działalność polityczną. Rozpad Christianitas postawił bowiem przed uczestnikami sporu po raz kolejny pytania o źródła i istotę władzy i prawa. Tak jak inni protestanci także i on po odrzuceniu Tradycji mógł się zwrócić tylko ku Pismu Świętemu. Dlatego w okresie reformacji mamy do czynienie ze szczególnym podkreśleniem supremacji Prawa Bożego, a zawarte w Słowie nakazy były jedynym probierzem dobra i zła oraz przewodnikiem po teorii politycznej. Ten jego bezapelacyjny prymat powodował, że nikt, ani król, ani wspólnota, nie mógł podążać inną ścieżką niż ta wytyczona przez Biblię. Szczególnie szkoccy teologowie opierali swe rozważania na argumencie biblijnym, a odrzucając scholastykę i logiczne spekulacje, pracowali na Piśmie w językach oryginalnych w interakcji

${ }^{4}$ D.F. Kelly, The Emergence of Liberty in the Modern World. The Influence of Calvin on Five Governments from the 16th Through 18th Centuries, Philipsburg 1992, s. 131.

5 O. Chadwick, The Reformation, Harmondsworth 1964, s. 403. 
z jego patrystyczną średniowieczną i reformowaną interpretacją ${ }^{6}$. Było ono dla nich nie tylko wyznacznikiem dobra i zła, wskazówką, jak oddawać cześć Bogu i dążyć do Królestwa Niebieskiego, lecz także podręcznikiem polityki, w którym znaleźć można było archetyp porządku podobającego się Bogu.

Wedle Rutherforda zatem człowiek funkcjonuje w dwóch równoległych porządkach: porządku natury i porządku łaski. Porządek natury określany jest regułami prawa natury, zrównywanymi przez Rutherforda z prawem Boskim, regułami, które wyryte zostały pierwotnie w sercu Adama i choć zniekształcone przez grzech pierworodny, to ciągle obecne w pewnym stopniu w duszy każdego człowieka. „To, co jest uzasadnione przez naturalne światło — pisze — jest uzasadnione przez prawo natury i w konsekwencji przez prawo boskie; któż bowiem może zaprzeczyć, że prawo natury nie jest boskim prawem?"7. Kiedy Bóg stworzył pierwszego człowieka, zaszczepił mu, tworząc go „na obraz i podobieństwo”, naturalną znajomość Boga, jego świętości, sprawiedliwości, miłosierdzia, wiedzę o tym, co dobre i złe, oraz wrodzoną skłonność do przestrzegania Bożych nakazów. Zasady te funkcjonują więc od czasów Stworzenia, są częścią ludzkiej natury, zanim zostały ogłoszone przez Mojżesza.

W tej wewnętrznej skrytce — pisze Rutherford — naturalnym zwyczaju moralnych zasad przetrwał rejestr wspólnych pojęć zostawionych nam przez naturę, starożytne zapiski i kroniki z czasów Adama i dwa tomy Prawa Natury. Pierwsza Tablica mówi, że jest jeden Bóg, który jest stworzycielem i władcą wszystkich rzeczy, że jest jeden Bóg, nieskończenie dobry, sprawiedliwie odpłacający za zło i dobro. Druga dotycząca ludzkich działań mówi, by kochać swych rodziców, słuchać zwierzchników, nie krzywdzić innych ludzi ${ }^{8}$.

Prawo natury zaszczepione zostało w człowieku, by mógł się nim kierować i odróżniać dobro od zła. Pochodzi od samego Boga, który zapisał je swą dłonią w naszych sercach i powiązał z ludzką naturą tak, by człowiek poznał, co to sprawiedliwość i dobro. Choć zgodnie z klasyczną kalwińską tradycją ${ }^{9}$ Bóg jest ,powszechnym i całkowitym Panem i Właścicielem nieba, ziemi i wszystkich, które w nich są"10,

${ }^{6}$ R. Letham, The Westminster Assembly. Reading its Theology in its Historical Context, Phillipsburg 2009, s. 105.

7 S. Rutherford, Lex, Rex, or The Law and the Prince; A dispute for The Just Prerogative of King and People: containing The reasons and causes of the most necessary defensive wars of the Kingdom of Scotland, and of their Expedition for the aid and help of their dear brethren of England; in which their innocency is asserted, and a full answer is given to a seditious pamphlet, entitled, Sacro-Sancta Regnum Majestatis, Robert Ogle and Oliver \& Boyd, Edinburgh 1843, I, s. 1.

${ }^{8} \mathrm{~S}$. Rutherford, A free disputation against pretended liberty of conscience tending to resolve doubts moved by Mr. John Goodwin, John Baptist, Dr. Jer. Taylor, the Belgick Arminians, Socinians, and other authors contending for lawlesse liberty, or licentious toleration of sects and heresies, Andrew Crook, London 1649, s. 7.

9 Zob. J. Calvin, Institutes of the Christian Religion, I, XVI, 7, przeł. F.L. Battles, Louisville 1960 , t. 1, s. 206.

${ }^{10} \mathrm{~S}$. Rutherford, The covenant of life opened, or, A treatise of the covenant of grace, Andro Anderson, Edinburgh 1655, s. 38. 
to w naturalnych ludzkich skłonnościach odbijają się Boskie zamiary. By jednak móc argumentować w prawdziwie chrześcijańskim stylu, Rutherford musi znaleźć w swej teorii prawa miejsce na łaskę. Zatem reguły te mogą być rozpoznane, na skutek upadku Adama, tylko za sprawą działalności Ducha Świętego, dlatego „natura nie jest wystarczającą wskazówką tego, co czynić, by osiągnąć życie wieczne"11. Bóg zaszczepił, przez prawo natury, w sercu człowieka pewne naturalne skłonności, które przyjmują formę nakazu i każą mu działać w określony sposób. Lecz człowiek naturalny, który nie zna prawdziwego Boga, jest nieświadomy podstaw swych zobowiązań. Toteż jego naturalne dobre działania są niedoskonałe, ponieważ motywowane są cielesną wolą i żądzą, a nie dlatego że rozkazał tak Stwórca w prawie natury ${ }^{12}$. Do porządku natury należy z samej istoty bycie częścią Bożego dzieła, do porządku zaś łaski jedynie na mocy wybraństwa. Skoro więc sama natura nie wystarcza jako źródło norm moralnych, potrzebne jest Słowo Boże, by zrozumieć zamiar Stwórcy wobec rodzaju ludzkiego. Do pełnego rozumienia natury konieczny jest więc boski autorytet Pisma Świętego, łaska więc nie przekreśla natury, lecz ją udoskonala. Słowo i Duch muszą działać więc razem, Słowo jest rozumne, lecz wymaga Ducha, a Duch działa tylko przez Słowo.

\section{Władza i geneza porządku politycznego}

Istnienie społeczeństwa jest więc dla Rutherforda częścią Bożego planu w tym sensie, że jednostki dążą do realizacji tej tkwiącej w ich naturze skłonności jako elementu prawa naturalnego. Źródłem tego są naturalne skłonności zaszczepione w ludzkiej naturze. Ich zaś źródłem jest naturalny rozum, który Rutherford nazywa „osądem Boga"13. Prawo natury jest więc rozumem wiodącym ludzi ku społeczeństwu politycznemu. Idea społeczeństwa jest zatem częścią porządku natury ${ }^{14}$, natomiast jej realizacja następuje już w porządku łaski/konwencji i w tym sensie fundamentalnie różni się od rodziny, do której przynależność nie jest zasadniczo kwestią wyboru czy decyzji, lecz instynktu. O ile idea społeczeństwa zaszczepiona jest w ludzkiej duszy od czasów Kreacji, o tyle powstanie społeczeństwa ma charakter dobrowolnej agregacji, choć realizującej przyrodzoną człowiekowi skłonność.

11 S. Rutherford, The divine right of church-government and excommunication: or a peacable dispute for the perfection of the holy scripture in point of ceremonies and church government, John Field, London 1646, s. 76.

12 Ibidem, s. 79.

13 S. Rutherford, Lex, Rex, I, s. 5.

14 Podobnie jak prawo własności, o którym pisze: „Jest moralnie niemożliwe, by nie było rozróżnienia na meum et tuum, moje i twoje; i dziesięć przykazań Bożych zabraniających kradzieży i pożądania żony innego mężczyzny [...] jest dowodem, że podział rzeczy jest częścią (choć ludzie są obecnie w stanie grzechu) prawa natury tak dalece, iż jest oczywistą podstawą prawa narodów", ibidem, XVI, s. 67-68. 
Człowiek rodzi się z natury wolny od wszelkiego poddaństwa z wyjątkiem tego, które jest najmilsze i najbardziej naturalne, czyli podporządkowania ojcowskiego lub synowskiego, albo podporządkowania żony mężowy, szczególnie zaś wolny jest od naturalnego podporządkowania księciu ${ }^{15}$. [...]

Ponieważ społeczeństwo domowe jest naturalnym przykładem, tak społeczeństwo obywatelskie jest naturalne in radice w swych korzeniach, lecz dobrowolne in modo, jeśli chodzi o sposób połączenia. Zakładając więc, że ludzie łączą się w społeczeństwo lub że społeczeństwo nie zawiera się w rodzinie, wtedy naturalne jest, że ludzie przyłączają się do społeczeństwa obywatelskiego, choć sposób zjednoczenia w ciele politycznym, jak mówi Bodin, jest dobrowolny ${ }^{16}$.

U Rutherforda społeczeństwo przyjmuje zatem, przynajmniej na poziomie koncepcyjnym, formę dobrowolnej agregacji wolnych i równych jednostek jednoczących się dla wspólnego celu istniejącego już wcześniej w ich świadomości.

Ta kontraktualna geneza dotyczy u niego jednak nie tylko społeczeństwa, lecz także władzy politycznej. Pierwszy jednak problem, jaki podnosi Rutherford w swej analizie, problem, który ostatecznie determinuje jego wszystkie dalsze rozważania, to kwestia samej władzy. Dlatego powołując się na argumenty z Listu do Rzymian $\left(13,1-4^{17}\right)$, że sama idea władzy pochodzić musi od Boga, dowodzi:

Cała władza polityczna wywodzi się bezpośrednio z Boskich korzeni, ponieważ: 1. Bóg uczynił człowieka istotą społeczną i ten, kto pragnie być rządzony przez człowieka z pewnością musiał umieścić tę moc w ludzkiej naturze z dobrego powodu, jak naucza Arystoteles. 2. Bóg i natura mają na celu politykę i pokój ludzkości, stąd Bóg i natura dały ludzkości moc, by zmierzyła się z tym celem, i musi nią być władza rządu ${ }^{18}$.

Stąd z samej społecznej natury człowieka, powołanej do życia przez Stwórcę, determinującej konieczność wspólnego bytowania wynika potrzeba istnienia władzy mogącej zapewnić wspólnocie przetrwanie i pokój. Jak w całej niemal tradycji reformowanej dla Rutherforda państwo jest więc ustanowionym przez Boga porządkiem narzuconym na upadłego człowieka jako remedium na jego grzech. Relacje społeczne, z racji zdeprawowanej ludzkiej natury, nie są bowiem pokojowe i bezkonfliktowe.

Jeśli — pisze Rutherford - wszyscy byliby bezgrzeszni, nie czyniliby innym gwałtu, prawo mogłoby rządzić wszystkimi i wszyscy ludzie mogliby je egzekwować, agendo sponte, przez czynienie dobra z własnej woli, to nie potrzebowaliby króla, który zmuszałby ich do tego. Ale ponieważ ludzie z natury sprzeciwiają się dobrym prawom, dlatego istnieje potrzeba władcy ${ }^{19}$.

15 Ibidem, XIII, s. 51.

16 Ibidem, II, s. 1-2.

17 W Biblii króla Jakuba fragment ten brzmi następująco: „Let every soul be subject unto the higher powers. For there is no power but of God: the powers that be are ordained of God" (The Holy Bible, Baker, London 1611, [b.p.], wyd. pierwsze).

18 S. Rutherford, Lex, Rex, s. 1.

19 Ibidem, XXII, s. 101. 
Musi więc istnieć siła, która zdolna będzie okiełznać indywidualne żądze dotkniętych grzechem ludzi i zjednoczyć ich wysiłki w jednym kierunku. Dlatego „Królewskie imperium jest zasadniczo po to, by nakarmić, kierować, obronić oraz rządzić w pokoju i pobożności (1 TM. II.2) jak czyni to ojciec swych dzieci" 20 . „Chrystus używa chrześcijańskich urzędników jako swe sługi, by przegonić wilki od swej trzody"21. Rządzący są zatem publicznymi sługami chroniącymi społeczeństwo i wykonawcami woli Boga dla dobra, bezpieczeństwa, pokoju i zbawienia ludzi. Społeczeństwo bez władzy jest zatem społeczeństwem niepełnym, które zniszczyć może samo siebie. Rząd jest więc konieczny, by powstrzymać zło oraz zachować pokój w społeczeństwie, i Bóg musiał zaszczepić w świadomości człowieka środki osiągnięcia tych celów ${ }^{22}$. Wbrew władzy grzechu rozum, umocniony łaską, potrafi dostrzec naturalne prawo, którym powinien się kierować. Dlatego oświecone prawem natury zjednoczone w społeczeństwie jednostki dojść muszą do konkluzji, że konieczne jest istnienie władzy wyposażonej w prawo miecza.

Zastanawiając się nad genezą państwa, Rutherford odrzuca teorię boskiego prawa królów, z którym Lex, Rex jest bezpośrednią polemiką (jest bowiem bezpośrednią odpowiedzią na traktat królewskiego kapelana Johna Maxwella Sacro-sancta Regum Majestas, or, The Sacred and Royal Prerogative of Christian $K_{i n g s}{ }^{23}$ ). Miast tego przekonuje o kontraktowej genezie porządku politycznego. I tutaj też dzieje się to za sprawą naturalnego przyrodzonego instynktu, który kieruje ludzi ku władzy, powodując, że ,przekazujemy naszą władzę w ręce jednego lub większej liczby władców"24. Co ważne przy tym:

indywidualne osoby, powołując władzę, nie zrzekają się swych uprawnień, lecz zrzekają się swej władzy zadania gwałtu innym członkom wspólnoty. Zatem nie będą mieć moralnego prawa czynienie krzywdy bez kary; i to nie jest uprawnienie czy wolność, lecz służebność, ponieważ władza stosowania przemocy i czynienia krzywdy nie jest wolnością, lecz służebnością i poddaństwem ${ }^{25}$.

Dlatego ludzie muszą z konieczności ich wyznaczyć i poddać się ich władzy, by móc realizować jedyną wolność, jaką Rutherford ma na myśli, czyli możliwość moralnego życia w chrześcijańskim państwie. Prawo natury wyznacza więc konieczność realizowalną w akcie woli człowieka. Jako dobry kalwinista uzasadnienia szukać musi oczywiście w Piśmie Świętym, mającym nieocenioną moc perswazyjną. Dlatego odwołując się do Deuteronomium 17:14, 15, wskazuje, że mimo iż król Izraela musiał zostać wskazany przez Boga, to ostatecznie jego wyniesienia dokonywali ludzie. Albowiem jeśli ludzie nie posiadaliby takiej władzy,

20 Ibidem, XVI, s. 64.

21 S. Rutherford, A free disputation, s. 192.

22 W.M. Campbell, Lex, Rex and its Author, „Scottish Church History Society” 1941, s. 216.

23 R. Flinn, Samuel Rutherford and Puritan Political Theory, „Journal of Christian Reconstruction" 5, 1978-1979, s. 50-51.

${ }^{24}$ S. Rutherford, Lex, Rex, II, s. 2.

25 Ibidem, VII, s. 25-26. 
to Bóg nie mógłby nakazać im dokonania tego, ograniczając się jedynie do wskazania władcy. Co więcej, nawet gdy Bóg uświęcił linię Dawidową, to każdoczesny władca, mimo że posiadł władzę na mocy dziedziczenia, nie mógł władać bez przyzwolenia ludu. Władza wynoszenia królów jest więc immanentnie przypisana ludowi, którego zgoda każdocześnie legitymuje króla.

Władza ta jest radykalnie naturalna, tak samo jak pszczoły (jak sądzą niektórzy) mają moc wyboru swej królowej, tak wspólnota ma naturalną władzę bronić się i ochraniać; i Bóg objawił w Deut. XVII. 14, 15 sposób wyboru naczelników i królów, który jest specjalnym środkiem obrony i ochrony; a lud jest głównym źródłem i fontanną władzy królewskiej ${ }^{26}$.

Pamiętać należy jednak, że ich wybór kierowany jest przez Boga, zatem, co bardzo dla Rutherforda istotne: „nie możemy mówić tutaj o dwóch aktach, jednym Boga, drugim ludzi, ale o jednym i tym samym działaniu; Bóg przez wolny wybór i głos ludzi czyni takiego człowieka Królem, pomijając tysiące innych"27. W ten sposób władza pochodzi bezpośrednio od Boga i bezpośrednio od ludzi, zatem „Bóg tylko przez działanie ludzi jako, jego narzędzia, może uczynić królem; Bóg tylko przez działanie ludzi, jako jego narzędzia, może zdetronizować króla"28. Odwołując się do De legibus Suáreza, dowodzi więc, że Bóg jest bezpośrednim autorem władzy politycznej w tym znaczeniu, że stworzył ludzi, którzy z natury muszą mieć władzę, by móc funkcjonować we wspólnocie. Była ona naturalna także w tym znaczeniu, że ludzie przenosili władzę polityczną całej wspólnoty, która jest elementem porządku natury, na rządzących, by realizowali jej naturalne funkcje ${ }^{29}$. „Bóg daje władzę królewską, poruszając serca ludzi, by przyznali władzę królewską, która jest faktycznie w ludziach, formalnie zaś od Boga"30. Choć władza królewska została wymyślona przez Boga, nie przez ludzi, to w rezultacie powołana została w poszczególnych państwach za sprawą ich woli. Co prawda więc za istnieniem poszczególnych rządów stoi Bóg, lecz ludzie zostali aktywnie włączeni w proces ich tworzenia. Władza rządzących pochodzi więc od Boga przez dokonujących jej wyboru ludzi. Ma charakter umowy zawartej na określonych warunkach, ,,jest to oczywiste zobowiązanie Króla wobec ludu w akcie koronacji i ludu wobec króla, jak w umowach między panem a wynajętym sługą czy między dwoma kupcami” 31 . Racjonalny namysł realizuje więc przyrodzoną naturalną konieczność, lecz w sposób przez naturę niezdeterminowany, dlatego „Bóg wyznaczył króla lub naczelnika, który troszczyć się będzie o tę wspólnotę, będzie rzą-

26 Ibidem, XL, s. 203.

27 Ibidem, IV, s. 7.

28 Ibidem, XL, s. 202.

29 J.D. Ford, Lex, rex iusto posita: Samuel Rutherford on the origins of government, [w:] Scots and Britons Scottish political thought and the union of 1603, red. R.A. Mason, Cambridge 1994, s. 268.

30 S. Rutherford, Lex, Rex, V, s. 11.

31 Ibidem, s. 218-219. 
dzić nią w pokoju i ochroni wszystkich przed wzajemnymi aktami przemocy"32. Bez króla istnienie sprawiedliwego społeczeństwa jest fizycznie niemożliwe, bez niego anarchia i gwałt wezmą górę, dlatego jego ustanowienie jest obowiązkiem zaszczepionym w umyśle przez światło natury. Rutherford ujmuje to następująco:

Po pierwsze, wyznaczenie przez rzeczpospolitą władców, by rządzili, nie jest czynem obojętnym, lecz moralnym, ponieważ ich nieustanowienie jest, jak myślę, naruszeniem piątego przykazania. Po drugie, w zakresie wolnej woli ludzi nie ma wyboru między istnieniem a nieistnieniem rządu, ponieważ nie należy do wolnej woli posłuszeństwo lub nieposłuszeństwo wobec sądu natury, który jest sądem Boga, a sąd ten stwierdza, że społeczeństwa cierpią, a ludzkość ginie, gdy nie wyznaczy się żadnego rządu ${ }^{33}$.

Do jego powołania dochodzi więc wskutek horyzontalnie rozumianego przymierza, w którym równe sobie umawiające się strony dokonują powołania państwa, jedna strona kontraktu staje się władcą, pozostałe jej poddanymi. Dochodzi do wzajemnego zobowiązania (mutual covenant), zgodnie z którym król rządzi według prawa, ludzie są zobowiązani do posłuszeństwa władzy, a obie strony uprawnione są do wymagania od drugiej strony przestrzegania warunków umowy. Kontrakt ten nie może zostać w normalnych warunkach anulowany, chyba że na mocy zgodnej woli obu stron. Zatem król nie stoi ponad przymierzem i ponad prawem, które uczyniły go królem. Królowie, którzy są rozumnymi ojcami i przewodnikami swego ludu, którzy władają zgodnie z prawem, dbają o pokój wewnętrzny i bezpieczeństwo, wyprowadzają swą władzę z kontraktu i przymierza z ludem, stając się strażnikami wszystkich dobrych praw. Symbolicznym zaś aktem zawarcia przymierza i poddania prawu jest koronacja oraz przysięga koronacyjna. W ten sposób Rutherford stara się zdezawuować rojalistyczne stanowisko negujące istnienie jakiegokolwiek kontraktu o władzę. Maxwell czy Barclay stali na stanowisku, że jedyny kontrakt, jaki istnieje, zawarty jest między Bogiem a królem, bez udziału poddanych. Ruhterford ten typ umowy wpisuje jednak w swoją rozbudowaną argumentację, nadając mu całkowicie odmienny od rojalistów sens. Podobną konstrukcję widać już w Vindiciae ${ }^{34}$, w którym autor pisze o

dwóch rodzajach przymierzy zawartych podczas wyniesienia króla, pierwszym pomiędzy Bogiem, królem i ludem, by lud mógł być ludem Bożym, oraz drugim, pomiędzy królem i ludem, gdzie ludzie podporządkowują się do posłuchu wobec sprawiedliwych rozkazów króla ${ }^{35}$.

Jednak gdy wywód zawarty w Vindiciae contra tyrannos, przypisywanym Philippe’owi de Mornay Du Plessis, służy uzasadnieniu tolerancji religijnej, Rutherford zmierza w odmiennym kierunku, zgodnym z doświadczeniami szko-

32 Ibidem, XVII, s. 69.

33 Ibidem, III, s. 5.

34 J.H.M. Salmon, The French Religious Wars in English Political Thought, Oxford 1959, s. 87.

35 Junius Brutus, Vindiciae contra Tyrannos: A Defence of Liberty against Tyrants, or Of the lawful power of the Prince over the People, and of the People over the Prince, Richard Baldwin, London 1689, s. 8. 
ckimi cechującymi się skrajną nietolerancją. W teologii politycznej Rutherforda kontrakt/przymierze przybiera bowiem ostatecznie dwoistą, horyzontalną i wertykalną postac ${ }^{36}$.

\section{Umowa z Bogiem}

Pokolenie Anglików, urodzone już po rewolucji purytańskiej i krótkim republikańskim epizodzie, na którego życie przypada stopniowa sekularyzacja, po przeby tej traumie, filozofii politycznej zapoczątkowało oddzielenie świeckich i religijnych elementów koncepcji przymierza ${ }^{37}$. Wraz z marginalizacją roli Boga w kontrakcie między władzą a poddanymi zatracał się jednak najistotniejszy element konstytuujący samą ideę Covenant. Sam Rutherford widział zresztą początek tych tendencji, upatrując w Grocjuszu zapowiedź powstania teorii politycznych wolnych od teologicznych założeń. Albowiem istotne w teoretycznej konstrukcji kontraktu o władzę Rutherforda i innych kalwińskich teoretyków jest to, że wbrew pozorom nie ma on tylko charakteru poziomego. Oprócz warunków określonych przez lud i sprowadzających się generalnie do jego obrony jest jeszcze warunek niezależny od woli umawiających się stron. Celem państwa jest zabezpieczenie pomyślności poddanych przez ochronę ich oraz Kościoła, by mogli osiągnąć dobro najwyższe, jakim jest poznanie Boga. Władca zobowiązany jest bowiem przed Bogiem do obrony prawdziwej religii. Jest to zatem to, co nazwać można mianem aggressive covenantalism, a zatem forma przymierza, która zgadza się z potrzebą istnienia właściwego porządku społecznego, lecz określa granice władzy i warunki prawa oporu w kategoriach bardziej religijnych niż stricte prawnych ${ }^{38}$. Wiąże się to u Rutherforda bezpośrednio z koncepcją covenant i szczególną rolą, jaką przypisuje Wyspiarzom w budowie Królestwa Bożego. Już intelektualny mistrz Rutherforda przekonywał bowiem, że Anglicy i Szkoci to narody, które zawarły przymierze z Bogiem, wcielając na nowo starotestamentową ideę ${ }^{39}$.

Dwa parlamenty Szkocji i Anglii odnowiły przymierze nie przeciw królowi, ale by przywrócić religię do starożytnej czystości mając to prawo wyraźnie od króla Jakuba i Karola oraz wiele aktów parlamentu, by utrzymać religię czystą ${ }^{40}$.

36 J. Coffey, Politics, Religion and the British Revolutions. The Mind of Samuel Rutherford, Cambridge 1997, s. 165.

37 D.J. Elazar, Covenant and Commonwealth. From Christian Separation through the Protestant Reformation. The Covenant Tradition in Politics, t. 2, New Brunswick 1998, s. 45.

38 G.A. Moots, Politics Reformed. The Anglo-American Legacy of Covenant Theology, Columbia-London 2010, s. 64.

39 M. Steele, The 'Politick Chritian'. The Theological Background to the National Covenant, [w:] The Scottish National Covenant in its British Context, red. J. Morrill, Edinburgh 1990, s. 46. 40 S. Rutherford, Lex, Rex, XXVI, s. 136. 
Te dwa królestwa mają przed sobą cel, jakim jest przymierze, by być ludem Bożym. Niech błogosławi im Pan, który pośredniczy dla zapobieżenia ich zerwaniu i działa dla trwania tego braterskiego przymierza. Chrystus jest jednoczącym Zbawcą, jedynym Bogiem, jedną wiarą, jednym Panem Jezusem Chrystusem, powinna być więc jedna religia, dlatego prosimy Boga pokoju, by połączył złotymi łańcuchami te dwa narody razem in uno tertio, by były zgrupowane i połączone w jednym Panu Jezusie ${ }^{41}$.

Pisze to Rutherford o sojuszu między Szkotami i angielskim parlamentem w czasie Wielkiej Rebelii, który przybrał formę Solemn League and Covenant. Był więc traktowany w kategoriach religijnego przymierza ${ }^{42}$, a sam dokument zredagowany został przez Alexandra Hendersona - jednego ze szkockich delegatów do Westminsteru ${ }^{43}$.

Dla Rutherforda zatem, jak reszty Covenanters $^{44}$, cała historia Szkocji i jej konstytucja mogły być analizowane z takiej perspektywy. Rozpoczęła się bowiem w istocie w 205 roku, gdy kraj ten przyjął chrześcijaństwo, zawierając przymierze z Bogiem. Z czasem jednak został uwiedziony przez błędy papiestwa, zrywając ze Stwórcą tę szczególną relację ${ }^{45}$. Na szczęście reformacja przyniosła powrót do czystości religii i odnowione zostało przymierze między ludem Szkocji a Chrystusem $^{46}$, czyniąc ze Szkotów naród wybrany i inkarnację Izraela ${ }^{47}$, a Kirk ,,jednym z najczystszych dziś kościołów pod niebem, zarówno w szacunku dla prawdziwej doktryny, jak i czystości kultu'48. Dlatego w swoim liście do braci z Irlandii napisał, z entuzjazmem odnosząc się do postępów reformacji, że „Chrystus został intronizowany i Jego chwała wzrosła na całym świecie, szczególnie zaś w tych trzech królestwach"49. Przeniknięty apokaliptycznym duchem mógł też stwierdzić: „Teraz, o Szkocjo, dzięki Bogu, twoje imię jest w Biblii" ${ }^{50}$. Szedł więc śladem Knoxa, który dowodził wcześniej ciągłości przymierza między Szkocją a Izraelem, od Abrahama, przez Mojżesza, Dawida aż po Chrystusa. Zatem władcy tego

41 S. Rutherford, To The Right Honorable and Noble Lord, The Earl of Lovden, Chancellor of Scotland; and Chancellor of the University of St. Andrews, Grace, Mercy and Peace, [w:] idem, The divine right of church-government and excommunication, [b.p.].

42 P. Toon, Puritans and Calvinism, Swengel 1973, s. 38.

43 W.M. Hetherington, History of the Church of Scotland from the introduction of Christianity to the period of the disruption of 1843, Robert Carter \& Brothers, New York 1851, s. 186.

44 Terminem tym zwykło określać się sygnatariuszy Narodowego Przymierza z roku 1638, wymierzonego przeciwko próbom narzucenia Szkocji przez Karola I Modlitewnika; J. Coffey, The Impact of Apocalypticism during the Puritan Revolutions, „Perichoresis” 4, 2006, nr 2, s. 122.

45 R.A. Mason, Imagining Scotland, [w:] idem, Scots and Britons Scottish political thought and the union of 1603, s. 13.

46 Ch. Hill, The English Bible and the Seventeenth-Century Revolution, London 2014, s. 182.

47 S.A. Burrell, The Covenant Idea as a Revolutionary Symbol: Scotland, 1596-1637, „Church History" 27, 1958, s. 348.

48 The Booke of the Universall Kirk. Acts and Proceedings of the General Assemblies of the Kirk of Scotland, 1560-1618, Maitland Club, Edinburgh 1845, t. 3, s. 1139.

49 To the Honourable, Reverend, and Well-Beloved Professors of Christ and His Truth in Sincerity, in Ireland, [w:] S. Rutherford, Letters, Co.Waterford, London 1857, s. 15.

50 S. Rutherford, Fourteen communion sermons, Bonar, Glasgow 1877, s. 116. 
królestwa są zobowiązani rządzić nimi zgodnie z Bożą wolą i popierać prawdziwą wiarę $^{51}$. W swoim Appellation (adresowanym do biskupów Szkocji) podkreślał, że, by cieszyć się życiem wiecznym, odrzucić należy rzymskie bałwochwalstwo, Anglia i Szkocja powołane zostały bowiem, by dochować przymierza z Bogiem, a posłuszeństwo jest warunkiem Bożego miłosierdzia ${ }^{52}$. Odrzucenie bałwochwalstwa i przestrzeganie prawa Bożego jest więc najważniejszym elementem kontraktu ze Stwórcą. Dlatego rządy katolickich władców były dla niego złamaniem przymierza, rządami bałwochwalców i tyranów, przed którymi wspólnotę może ochronić jedynie aktywne stawienie oporu ${ }^{53}$. Wedle Knoxa, by utrzymać przymierze z Bogiem, władza cywilna, podobnie jak w Izraelu i Judzie, musi dbać o czystość religii ${ }^{54}$. Między innymi za jego sprawą w szkockim kalwinizmie, pod wpływem koncepcji hugenockich ${ }^{55}$, skrystalizował się więc pogląd, że przymierze religijne jest trójstronnym kontraktem między królem, ludźmi a Bogiem, by strzec czystości prawdziwej zreformowanej religii i Kościoła. Działanie w jego ramach było $\mathrm{w}$ istocie kontraktem konstytucyjnym między królem z jednej, a ludem z drugiej strony dla zachowania porządku, dobrego rządu i ochrony religii ${ }^{56}$.

Dlatego Rutherford też przekonany jest o przymierzu wzorem starożytnego Izraela łączącym Szkocję z Bogiem. W jego narracji historia Szkocji podobna jest do dziejów starożytnego Izraela i tak samo jak Izrael Szkocja stała przed wyborem: posłuszeństwo Bogu przynieść miało błogosławieństwa, nieposłuszeństwo zaś przekleństwo i katastrofę. Katastrofę, której można było uniknąć, całkowicie zawierzając Bogu i stając się początkiem powszechnego odkupienia przez odrzucenie rzymskiego Antychrysta i ustanowienie rządów Boga nad wszystkimi narodami ziemi. Konsekwencją tego „Narodowego Przymierza” jest obowiązek „wykorzenienia wszystkich fałszywych religii, które są przeciwne prawdziwej doktrynie" ${ }^{27}$. Anglia zaś winna dokonać tego samego — odnowić przymierze zerwane przez odstępstwo na rzecz rzymskiego bałwochwalstwa (które dla Rutherforda ,jest obrzydliwe tak jak kult Dagona i bogowie Sydonu"58) — opierając swą konstytu-

51 W. Stanford Reid, John Knox. The First of the Monarchomachs?, [w:] The Covenant Connection. From Federal Theology to Modern Federalism, red. D.J. Elazar, J. Kincaid, Lanham 2000, s. 122.

52 R. Mason, Covenant and Commonweal: The Language of politics in Reformation Scotland, [w:] Church, Politics and Society. Scotland 1408-1929, red. N. MacDougall, Edinburgh 1983, s. 99.

53 R. Mason, Introduction, [w:] J. Knox, On Rebelion, Cambridge 1994, s. xi-xii.

54 J. Knox, A Brief Exhortation to England, for the Speedy Embracing of the Gospel Heretofore by the Tyranny of Mary Suppressed and Banished 1559, Dallas 1995, s. 3-4; zob. M.Ch. Bell, Calvin and Scottish Theology. The Doctrine of Assurance, Edinburgh 1985, s. 42.

55 J. Lockwood O'Donovan, Political Authority and European Community: The Challenge of the Christian Political Tradition, „Scottish Journal of Theology” 47, 1994, nr 1, s. 8-9.

56 A.I. Macinnes, The Scottish Constitution, 1638-51. The Rise and Fall of Oligarchic Centralism, [w:] The Scottish National Covenant in its British Context, s. 110.

57 S. Rutherford, A free disputation, s. 270.

58 S. Rutherford, Lex, Rex, XXXIV, s. 182. 
cję na przymierzu i wzorując na prawie naturalnym ${ }^{59}$. Jak powiedział w jednym z kazań, przykład Anglii stałby się impulsem dla reszty Europy, by wykorzenić rządy Antychrysta ${ }^{60}$. Był to jednak jedynie początek, ponieważ dla Szkotów, jak ujął to kompanion Rutherforda, celem było nawrócenie całej Europy ${ }^{61}$. Herezja ,jest bowiem grzechem przeciwko pierwszemu przykazaniu i tej nieskazitelnej zasadzie natury wyrytej w sercu człowieka, że jest tylko jeden prawdziwy Bóg i tylko jemu trzeba służyć" 62 . Dlatego jako chrześcijanin nie może ograniczać jedynie celów człowieka i całej wspólnoty do wymiaru doczesnego.

Każda władza - pisze Rutherford - by rozkazywać, grozić, obiecywać, karać, więzić, nagradzać, jest władzą daną przez Boga rodzicom, głowom rodzin, nauczycielom, opiekunom, Królom i Książętom, jest darem Boga i musi być wykorzystywany dla dobra dusz, by przestrzegać przykazań pierwszej Tablicy przez każdego, wedle jego pozycji. Stąd Książę, Parlament, podobnie Urzędnicy, zgodnie ze swą pozycją jako ojców wspólnego dobra muszą się o nie troszczyćc ${ }^{63}$.

Dlatego celem najważniejszym i ostatecznym musi pozostać ciągle zbawienie człowieka, a państwo personifikowane osobą władcy ma w tym pomóc i na którym ciąży szczególny obowiązek. Celem rządu jest stosowanie i realizacja prawa Bożego odkrytego przez doświadczenie i danego wprost przez słowa Pisma Świętego. Jest zatem formalnie ucieleśnieniem prawa Boga. Dlatego królowie „są Boskimi narzędziami i Sługami w: 1. Przedkładaniu i objaśnianiu praw Bożych; 2. W egzekwowaniu ich i obronie przed przemocą ludzi; 3. W tworzeniu praw politycznych, dla rządu politycznego, które wiążą sumienie dopóki zgodne są z Prawem Bożym"64.

W całej reformowanej teorii politycznej ,interes publiczny, dobro wspólne” są ostatecznym celem polityki, lecz rozumiane są przede wszystkim w kategoriach transcendentnych. Nie są zatem ograniczane do szczęścia i ukształtowania właściwych relacji społecznych, lecz jako realizacja Prawdy danej przez Boga człowiekowi i społeczeństwu. Wszystko inne zaś staje się w ten sposób skutkiem ubocznym, możliwym do ziszczenia, jeśli cel główny zostanie osiągnięty ${ }^{65}$. Warunkiem tego jest dla Rutherforda zachowanie czystości prawdziwej religii i walka z odstępstwem. W centrum wszechświata usytuowany jest nie człowiek, lecz jego Stwórca. Nadrzędny charakter przymierza z Bogiem jest fundamentem każdej chrześcijańskiej wspólnoty, a sprawiedliwość Boga wymaga posłuszeństwa w sprawach

59 J. Coffey, Politics, Religion and the British Revolutions, s. 144.

${ }^{60}$ Fear not, thou worm Jacob. (No. 2.) Isa. xli. 14-16, [w:] S. Rutherford, Quaint Sermons, Hoddes and Stoughton, London 1885, s. 36.

${ }^{61}$ R. Baillie, My Assembly Speech: [At Edinburgh, Thursday the 23d of January, 1645], [w:] The Letters and Journals of Robert Baillie, 1637-1662, t. 2, Bannatyne Club, Edinburgh 1841, s. 257.

62 S. Rutherford, A free disputation, s. 187.

63 Ibidem, s. 145.

${ }^{64}$ S. Rutherford, The divine right of church-government and excommunication, s. 208.

65 S. de Freitas, A. Raath, Samuel Rutherford and the protection of religious freedom in early seventeenth-century Scotland, „Historical and Theological Studies” 78, 2016, s. 242. 
religii. „Jeśli wierzymy w Chrystusa jako Pana i dawcę Praw, to formalnie zgadzamy się na zwierzchnictwo Chrystusa i jego władzę, ponieważ niewiara jest rebelią przeciwko jego rządom"66. Dlatego każdy, kto pragnie pozostać w przymierzu ze Stwórcą, przestrzegać musi bezwzględnie prawa Bożego. Król w tej perspektywie jest tarczą, broniącą nie tylko ciał poddanych, lecz także ich dusz przed odstępstwem i niewiarą. Jest karmicielem i stróżem, jest obrońcą ciała i duszy. Przestrzeganie prawa Bożego jest $\mathrm{z}$ tej perspektywy fundamentalnym i najważniejszy warunkiem sprawowania urzędu królewskiego, a poddani zobowiązani są posłuch nie wobec osoby, lecz urzędu właśnie, póki król znajduje się w przymierzu z Bogiem. „Królowie i zwierzchnicy lub rządcy — czytamy — są wysłani przez Boga, by karać złe uczynki i działać dla jego chwały, mają karać wszystkich fałszywych nauczycieli, którzy rujnują dusze innych i niszczą Kościół" ${ }^{\prime 7}$. Warunek ten nie musi być nigdzie zapisany, nie musi być wyrażony wprost, jest naturalny i wynika z samej istoty urzędu królewskiego ${ }^{68}$. Dlatego

Król jako człowiek, jest bardziej zobowiązany do publicznej i królewskiej obrony prawdziwej religii, niż jakikolwiek inny człowiek w kraju. Ponieważ został uczyniony królem przez Boga i ludzi dla kościoła i ludu Bożego, dlatego może bronić prawdziwej religii dla pomyślności i zbawienia wszystkich ${ }^{69}$.

Jak ujął to Henderson — kompanion Rutherforda — w roku 1638: „Obrona religii należy również do Króla, ponieważ jest do tego najodpowiedniejszy przez swój autorytet do obrony przed wszystkimi kłamstwami i nadużyciami, jako do strażnika pierwszej tablicy"70. Nie mówił przy tym nic nowego, albowiem Wyznanie wiary z 1560 roku mówiło wprost, że urzędnicy zostali wyznaczeni do „obrony prawdziwej religii i zwalczania bałwochwalstwa i przesądów". To zatem kontrakt wertykalny między władcą a Bogiem, podporządkowujący króla całkowicie woli Stwórcy. Bóg rządzi bowiem wszechświatem i daje ludziom ideę władzy jako środek osiągnięcia ich celów. To on jest więc pierwszą przyczyną wszystkiego, a ludzie tylko Jego agentami, wykonawcami Bożej woli. Zobowiązani są przez to do pełnego podporządkowania się jego nakazom i respektowania Prawa. Stąd władca jest zobowiązany przed nim do postępowania dla dobra swych poddanych i rządzić ma zgodnie z Jego wolą i prawami Bożymi.

Chrześcijański Król — przekonuje Rutherford — łagodnie i jako Chrześcijański Król ma służyć Chrystusowi Panu i ochraniać swą królewską godnością wszystkie nakazy Ewangelii w zewnętrzny polityczny sposób, zatem ma świadczyć królewską usługę Chrystusowi jako taki Król ${ }^{71}$.

66 S. Rutherford, The covenant of life opened, s. 175.

67 S. Rutherford, A free disputation, s. 186.

68 Ibidem, s. 146.

69 S. Rutherford, Lex, Rex, XIV, s. 56.

70 A. Stevenson, The History of the Church and State in Scotland from the Accession of King Charles I to the Year 1625. To which is Prefixed an Abstract of the State of Religion in Scotland, from the Earliest Acts of Christianity, to the Year 1625, Andrew Jack, Edinburgh 1844, s. 301.

71 S. Rutherford, A free disputation, s. 186. 
Rutherford w swej koncepcji kontraktu idzie jednak dalej, dowodząc starotestamentowymi przykładami (2 Krn XXI, 10, XIII, 8-10), że przymierze łączy także Boga i lud, dając mu możliwość obrony prawdziwej religii przed nastającym na nią monarchą ${ }^{72}$. Lud zatem przyjmuje podobne do króla zobowiązanie względem Króla królów. Umowa z Bogiem ma charakter dwustronny (choć oczywiście jednokierunkowo), zatem gdy lud złamie przyrzeczenia dane Stwórcy, odchodząc od prawdziwej religii, wtedy i Bóg nie jest zobowiązany do spełnienia swojej części porozumienia, „ponieważ król jest zobowiązany wobec Boga zachować prawdziwą religię, tak też lud i książęta są zobowiązani do tego w nie mniejszym stopniu"73. Zatem wszyscy urzędnicy i wszyscy poddani mają obowiązek troski o dobro Kościoła i obowiązek zwalczania herezji. Król nie jest bowiem dla Rutherforda głową Kościoła, a władza duchowa spoczywa też na pastorach, kaznodziejach i szanowanych członkach wspólnoty, którzy służąc Chrystusowi, mają prawo napominać władcę, jeśli ten błądzi w sprawach religii. W ten sposób więc można było uzasadnić opór przeciwko Karolowi w Szkocji i Anglii - jako próbę wyrugowania resztek rzymskiego bałwochwalstwa i zbudowanie prawdziwie chrześcijańskiego społeczeństwa. Powtarza zatem Rutherford niemal dosłownie tezy Knoxa, dla którego

karanie takich zbrodni jak bałwochwalstwo, bluźnierstwo i inne, które dotykają Boskiego Majestatu, nie należy tylko do króla i rządzących, lecz również do wszystkich ludzi razem i do każdego z osobna zgodnie z ich powołaniem, możliwościami i okazją, która daje Bóg, by pomścić przestępstwo przeciwko jego chwale ${ }^{74}$.

Warunkowy charakter władzy odnaleźć można zatem w kontrakcie horyzontalnym i wertykalnym, dotyczy tak samo relacji lud-władca, jak i Bóg-władca. Oczywiście Rutherford, pisząc o kontrakcie, nie miał na myśli żadnego konkretnego formalnego aktu czy dokumentu, nawet przysięga koronacyjna ma jedynie charakter deklaratoryjny. Naturalne przymierze między Bogiem, Królem i ludem dochodzi do skutku automatycznie w momencie powołania rządu, nawet gdy podczas tego aktu nie ma mowy o umowie. W ten sposób obowiązek rządzenia zgodnie z prawem Bożym nie jest elementem wyboru czy negocjacji, lecz elementem obowiązkowym dotyczącym wszystkich społeczeństw w każdym czasie ${ }^{75}$. Ludzie powołują warunkowo władcę dla ich obrony, a Bóg z ich pomocą zawiera z nim jednocześnie własny kontrakt na samej mocy jego urzędu i swej roli jako Króla królów. Ale lud jest związany przymierzem z Bogiem, a król jest częścią ludu, zatem już z samego tego faktu, jeszcze przed aktem wyniesienia, ciążą na nim konkretne wobec Stwórcy obowiązki (Rutherford odwołuje się tutaj do biblijnego przykładu Jojady [2 Kn 23, 16], który zawarł przymierze między Panem a całym ludem i królem).

72 J.W. Gough, The Social Contract. A Critical Study of its Development, Oxford 1975, s. 90

73 S. Rutherford, Lex, Rex, XIV, s. 55.

74 J. Knox, History of the Reformation in Scotland, Blackie\&Son, Glasgow 1841, s. 391.

75 R. Flinn, op. cit., s. 65. 
Bez tego wszelkie argumenty tracą jakikolwiek sens, utracony zostaje ich najważniejszy — religijny — kontekst. Ostatecznym celem wywodów Rutherforda nie jest bowiem jedynie ustrój, w którym władza podlega prawu oraz dba o dobro wspólne, lecz realizacja tych funkcji w ramach Respublica Christiana. Jak zauważył jeden z komentatorów, na pierwszy rzut oka filozofia polityczna Rutherforda przypominać może argumentację Locke'a, z jego kategorią samozachowania, rządami prawa i prawem oporu. Lecz $\mathrm{w}$ istocie zdeterminowana jest całkowicie chrześcijańską, postśredniowieczną jeszcze perspektywą. Jak inaczej wyjaśnić bowiem decydującą rolę Boga, troskę o prawdziwą religię z obowiązkiem zwalczania herezji i bałwochwalstwa? ${ }^{76}$ Jego prawo oporu w końcu, choć nie jest tematem niniejszego wywodu, jest nie tylko legitymowane naruszeniem przez władce kontraktu z poddanymi, lecz, podobnie jak u Knoxa czy Bullingera, heretyckim czy bałwochwalczym charakterem rządów. Samozachowanie nie oznacza bowiem u niego jedynie ochrony życia, lecz także, a może przede wszystkim zachowanie duszy przez zapobieżenie potępieniu.

\section{Przeciwko tolerancji}

Wertykalny aspekt kontraktu oraz typowa kalwińska perspektywa Rutherforda sprawiają, że jego koncepcja państwa jest w istocie jak najdalsza od tej, jaka dla czytelnika jednoznacznie kojarzącego konstrukcję umowy społecznej z państwem liberalnym i tolerancyjnym na pierwszy rzut oka wyłania się z lektury Lex, Rex. Traktaty teologiczne Rutherforda wymierzone są bowiem w to, co nazywa „udawaną wolnością", a przez co rozumie nauczanie sprzeczne z Wyznaniem wiary zatwierdzonym w Westminsterze, tworzenie i przynależność do jakiegokolwiek innego kościoła niż prawdziwy Kościół narodowy. Stoi więc w opozycji do independentów (których jeszcze rok przed Zgromadzeniem darzył sympatią ${ }^{77}$ ), całkowicie odmiennie postrzegając problem istnienie różnych denominacji. Ci ostatni w opinii Rutherforda i jego szkockich kompanionów, jakkolwiek była to opinia krzywdząca (Goodwin, Burroughs czy Owen wzywali bowiem do tolerancji dla pobożnych protestantów i odrzucali tolerancję dla tych, których religia była oczywiście fałszywa i destrukcyjna ${ }^{78}$ ), sugerowali wprowadzenie tolerancji będącej poparciem i akceptacją wszystkich opinii i interpretacji religijnych, uważając ją

76 J. Coffey, Politics, Religion and the British Revolutions, s. 187.

77 S. Rutherford, To the Christian Reader, [w:] idem, A peaceable and temperate plea for R. Pauls presbyterie in Scotland, or, A modest and brotherly dispute of the government of the Church of Scotland wherein our discipline is demonstrated to be the true apostolick way of divine truth, and the arguments on the contrary are friendly dissolved, the grounds of separation and the indepencie [sic] of particular congregations, in defence of ecclesiasticall presbyteries, synods, and assemblies, are examined and tryed, Iohn Bartlet, London 1642, [b.p.].

78 J. Coffey, Puritanism and Liberty Revisited: The Case for Toleration in the English Revolution, „The Historical Journal” 1998, nr 4, s. 963. 
za zachętę do rozpusty i rozluźnienia obyczajów. Dawałoby to pożywkę dla rozwoju sekt i herezji, w które i tak obfitowała ówczesna Anglia. Tymczasem szkocki prezbiterianizm reprezentuje prawdziwą biblijną formę Kościoła, a Kościół nie jest mistycznym ciałem złożonym $\mathrm{z}$ wiernych rozproszonych $\mathrm{w}$ rozmaitych sektach. Ta fałszywa koncepcja, która leży u podstaw religijnej tolerancji, jest oczywistym zaprzeczeniem celu, dla którego zwołane zostało Zgromadzenie Świętych ${ }^{79}$. Poglądy Rutherforda są zatem w tej kwestii jasne: prezbiterianizm szkocki reprezentuje Kościół Boga, zatem niedopuszczalne są żadne odchylenia; skoro tak, to wszyscy inni jako heretycy muszą zostać zniszczeni; tolerancja jako pożywka dla fałszywych doktryn jest niedopuszczalna; Pismo nie przewiduje żadnej tolerancji dla błędu; wolność sumienia generuje herezję i naraża jedność Kościoła; miecz jest środkiem ochrony dusz, chroniąc Kościół i wiernych przed błędem ${ }^{80}$. Trzeba jednak zauważyć, że nietolerancja w swej radykalnej postaci jest cechą charakterystyczną wyspiarskiej reformacji, także doświadczenia szkockie i poglądy choćby Knoxa nie pozostawiają w tej materii żadnych wątpliwości ${ }^{81}$. Zresztą Rutherford był świadkiem prześladowań purytanów w okresie rządów Lauda, którego wstecznie zaprowadzili na szafot.

Nie będąc zatem w tej kwestii oryginalnym na tle innych ojców reformacji, odrzuca Rutherford sceptycyzm w kwestii poznania prawdy religijnej. Stoi na gruncie jednej, którą można wprost odczytać z Biblii, dającej odpowiedzi na wszystkie pytania dotyczące prawdziwej wiary. To do niej, a nie do indywidualnego sumienia należy odwołać się w tej kwestii, ponieważ uczynienie sumienia wszystkich ludzi tworzy ,wiele Biblii różnych i przeciwnych Ewangeliom i słowu Bożemu oraz zasadom wiary i kultu"82. Dlatego przeciwstawiając się subiektywizmowi sekt, Rutherford twierdzi, że indywidualne sumienie prowadzić może na manowce, oddalając od Boga i ,jest w najlepszym przypadku tylko Regula Regulata, a nie Regulo Regulans, dlatego nie powinno zasiadać na tronie Bożym, ponieważ tylko Bóg jest Regulo Regulans" "83. Zatem sumienie prywatne musi ustąpić zinstytucjonalizowanemu sumieniu Kościoła określającemu prawdy wiary. Bóg umieścił w synodach Kościoła wyłączną i nieomylną władzę w tej materii, a wszyscy wierni muszą być związani ich decyzjami ${ }^{84}$. Każdy co prawda w swym sumieniu może wierzyć, w co chce, lecz nie ma prawa głosić tego publicznie. Gdy będzie to jednak czynić, musi być bezwzględnie potraktowany przez władzę kościelną i państwową. ,Takie opinie i praktyki — pisze — które stanowią ewidentną schi-

79 W.M. Hetherington, History of the Westminster Assembly of Divines, James Gemmell, Edinburgh 1878, s. 334.

80 D. Estrada, Calvinism versus Constantinism, „Christianity \& Society” 14, 2004, nr 2, s. 7.

81 A. Wielomski, Myśl polityczna reformacji i kontrreformacji, t. 1. Rewolucja protestancka, Radzymin 2013, s. 231-232.

82 S. Rutherford, A free disputation, s. 408.

83 Ibidem, 127.

84 D. Estrada, Rutherford as a Presbyterian Theologian and Political Thinker, „Christianity \& Society" 13, 2003, nr 4, s. 8 . 
zmę w Kościele i ustanawiają dwa odrębne Kościoły, różne formy rządów, i udają różne instytucje Chrystusowe pracując dla zniszczenia innych, nie mogą być tolerowane”, ponieważ ostatecznie prowadzą do tego, że „królestwo będzie wkrótce podzielone i zniszczony zostanie pokój i jedność" 85 . Tolerancja dla powstających jak grzyby po deszczu sekt musiałaby oznaczać porzucenie marzenia o religijnej jedności i postawiła pod znakiem zapytania sam sens reformacji ${ }^{86}$. Wzmacnia bowiem sceptycznego ducha kwestionującego pewność prawdy objawionej, którą Bóg obdarzył swój Kościół, niszczy człowieka, społeczeństwo i wiarę w Słowo Boże. Stąd w roku 1649 członkowie Komisji Zgromadzenia Ogólnego Kościoła Szkocji, wśród których był Rutherford, zaniepokojeni praktykami, jakie działy się w Anglii, przyjęli rezolucję przeciwko błędom i praktykom sekciarskim, przekazaną angielskiemu parlamentowi i prezbiterom. Komisja sprzeciwiła się rosnącym nastrojom tolerancji utrudniającym jej zdaniem ustanowienie chrześcijańskiego państwa. W konsekwencji tolerancji dochodzi do złamania przymierza z Bogiem z wszystkimi strasznymi konsekwencjami Bożego gniewu ${ }^{87}$. W tej perspektywie zdominowanej przez przymierze z Bogiem nie mieści się sytuacja, w której ludzie w chrześcijańskiej wspólnocie mogą wierzyć w to, co chcą, a władza patrzy na nich jak obojętny widz, nie troszcząc się o to, jaką religię wyznają, czy są papistami, żydami, poganami, anabaptystami czy socynianami. Dlatego George Gillespie, inny z Covenanters, z przerażeniem zauważył, że tolerancja „w Niemczech, we Francji, Holandii, Polsce, nawet pod turecką tyranią, w przeciwnej religii, w odmiennych praktykach i przekonaniach, jest zasadą państwową"88.

Co istotne Rutherford w swym traktacie nie poświęca w ogóle miejsca ewentualnym próbom nawrócenia przez władzę tych, którzy błądzą, ,ponieważ strach przed cielesną śmiercią i karą od miecza nie może sprawić nawrócenia"89. Przeciwnie, powinni być oni obiektem misyjnej działalności Kościoła i represyjnej działalności państwa, które z całą surowością karać powinny prowadzących wywrotową działalność słowem i pismem, ponieważ „urzędnik dzierży miecz po to, by wywrzeć zemstę na czyniących zło" 90 . Człowiek jako istota upadła musi otrzymać jasne drogowskazy dotyczące Bożej woli i sposobu wielbienia Stwórcy. Wolne sumienie, czyniące siebie probierzem Prawdy i tolerancja sprowadzić może go tylko na manowce. Dlatego w zamyśle Rutherforda państwo miało przestać być

85 S. Rutherford, A free disputation, s. 90.

86 R. Paul, The Assembly of the Lord. Politics and Religion in the Westminster Assembly and the Grand Debate, Edinburgh 1985, s. 47.

87 C. Gribben, Samuel Rutherford and Liberty of Conscience, „Westminster Theological Journal" 71, 2009, nr 2, s. 371.

${ }^{88}$ G. Gillespie, A late dialogue betwixt a civilian and a divine concerning the present condition of the Church of England in which, among other particulars, these following are especially spoken of..., Robert Bostock, London 1644, s. 30.

89 S. Rutherford, A free disputation, s. 55.

90 Ibidem, s. 44. 
instytucją grzechu, lecz ucieleśnieniem moralności i instrumentem jej osiągnięcia. Odwołując się do przykładów ze Starego Testamentu, pisze więc:

\begin{abstract}
Było nie mniej legalne dla sędziego w Izraelu, by zdominować i tyranizować sumienie fałszywego proroka, kapłana Baala, Dagona i by odpowiedzieć na argumenty kwestionujące doktrynę prawa Mojżeszowego tak lśniącego boskością, majestatem i mądrością Boga za pomocą miecza, ukamienowania, niż jest to dzisiaj dla chrześcijańskiego urzędnika, by ciężko pracować, aby zmienić fałszywego proroka za pomocą miecza lub topora dominującego nad jego sumieniem ${ }^{91}$.
\end{abstract}

Odwołując się do pierwszego przykazania, podobnie jak Knox ${ }^{92}$, wskazuje, że złorzeczący Bogu jako swemu Stwórcy, któremu powinien służyć, zasługuje na śmierć, bo choć Rutherford nie uważa, by wszyscy poganie, heretycy i katolicy zasługiwali na taką karę, to „pewne przykłady udowadniają, że kara główna powinna być wymierzona przez urzędnika wszystkim bluźniercom, wszystkim podżegaczom bałwochwalstwa i fałszywego kultu"93 , publicznie głoszącym heretyckie poglądy i mimo ostrzeżeń niekorygującym swych błędów.

Rząd, choć należący do porządku konwencji, lecz realizujący naturalne skłonności, musi być wyrazem autorytetu Boga. Dlatego musi korzystać z wyświęconego przez Boga miecza, by chronić Prawdę i prawdziwą religię. Tylko karząca ręka takiego państwa dzierżąca miecz jest $\mathrm{w}$ stanie zapobiec rozprzestrzenianiu się fałszywych poglądów. Kwestię odstępstwa traktuje przy tym Rutherford niebywale pryncypialnie, nie dokonując rozróżnienia na kwestie istotne i mniej ważne ${ }^{94}$. „Zatem urzędnik — czytamy — jako chrześcijanin, który jest zobowiązany strzec czci Boga i pokoju w całym społeczeństwie, jest tak samo zobowiązany, by karać fałszywe doktryny, niezależnie czy dotyczą prawd fundamentalnych, czy niefundamentalnych" 95 . Skoro istnieje tylko jedna Prawda reprezentowana przez prezbiterian, będących prawdziwym Kościołem Boga, to nie może być mowy nawet o najmniejszym odchyleniu ${ }^{96}$. Już Stary Testament (Pwt 13, 1-18, 17, 2-7) wskazuje jasno, że nie może być tolerancji dla bałwochwalców i fałszywych proroków. Nigdzie przy tym nie znajduje Rutherford uzasadnienia, że starotestamentowy nakaz zwalczania fałszywych nauczycieli został zniesiony. Co do dyskusji nad tym, czy prześladowanie heretyków i innowierców jest uzasadnione, Rutherford uznał za niedopuszczalną sugestię, że Bóg w Starym Testamencie był zbyt okrutny ${ }^{97}$. Nie traktuje tego jednak jako prześladowanie par excellence, prześla-

91 Ibidem, s. 362.

92 A. Wielomski, op. cit., s. 229.

93 Ibidem, s. 176.

$94 \mathrm{~S}$. Rutherford, The due right of presbyteries, or, A peaceable plea for the government of the Church of Scotland, E. Griffin, London 1644, s. 364.

95 S. Rutherford, A free disputation, s. 124.

96 D. Estrada, Rutherford as a Presbyterian Theologian and Political Thinker, s. 10.

97 S. Rutherford, The due right of presbyteries, s. 357. 
dowana może być bowiem jedynie prawda, a nie błąd. Ci zatem, którzy go głoszą, są na mocy prawa Bożego zwykłymi złoczyńcami na równi ze złodziejami i mordercami i na równi z nimi spotkać ich musi zasłużona kara.

Ponieważ tylko Bóg nie Mojżesz czy inny podległy mu prawodawca, określa, że na śmierć zasługuje cudzołożnik. I tylko On określa karę za umyślne morderstwo, uderzenie ojca lub matki, kradzież, czarnoksięstwo, sodomię, oddawanie czci obcemu bogu. Na tej samej zasadzie Bóg tylko, a nie jakiś śmiertelnik musi określić karę należną dla tych, którzy zwodzą dusze dla wiecznego potępienia ${ }^{98}$.

Powołując się na List do Rzymian 13, Rutherford podkreśla też, że władza dana przez Boga urzędnikowi ma być postrachem zła, a jej immanentną częścią jest kara dla tych, którzy rujnują dusze innych i niszczą Kościół. Tolerancja takich zachowań ,jest nie tylko sprzeczna z zewnętrznym spokojem wspólnoty i naturalnym szczęściem społeczeństw, lecz również sprzeczna z nadnaturalnym szczęściem Kościoła jako wspólnotą wiernych w drodze do szczęścia wiecznego". Nie można bowiem zbudować Republica Christiana tam, gdzie jest wiele religii, wiele interpretacji Pisma, gdzie każdy wedle swego sumienia oceniać może i interpretować Słowo Boże. Samą jego istotą jest bowiem postrzeganie wspólnoty politycznej jako tożsamej ze wspólnotą Kościoła. Choć obie są różne, to wzajemnie się przenikają, obie prowadzą do celów wobec siebie komplementarnych.

Reformacja w sposób całkowicie odmienny zaczęła postrzegać człowieka, jako istotę z gruntu złą i upadłą, a zatem konieczne stało się silniejsze oddziaływanie celem zachowania dyscypliny, która miała być przedmiotem troski Kościoła i państwa. Kalwini wierzyli bowiem, że prawdziwi chrześcijanie wiodą moralne życie i że struktura Kościoła powinna być ukształtowana zgodnie z biblijnymi zasadami, by pomagać wiernym $w$ ich osobistej walce z grzechem i bronić wspólnoty przed niemoralnymi i heretyckimi wpływami ${ }^{99}$. Klasycznym przykładem jest tu oczywiście Genewa - Kalwin wprowadził tu system, w którym śmiercią karane były herezja, bałwochwalstwo, bluźnierstwo, a także cudzołóstwo czy uderzenie rodziców. Straże pilnowały zaś, pod karą grzywny, obecności wszystkich w czasie uroczystości religijnych i mszy. Taniec, opilstwo, nieskromny ubiór groziły więzieniem, a hazardziści przykuwani byli do pręgierza. Czytanie niemoralnych książek było zakazane, a publiczne palenie zakazanych prac było na porządku dziennym. Nawet nadawanie imion katolickich świętych było niemile widziane przez konsystorz $^{100}$. Celem było bowiem społeczeństwo wolne od kłamstwa, a każdy chrześcijanin, i tego oczekuje od niego Chrystus, powinien pozwolić Bożemu światłu rozpraszać mrok tego upadłego świata. Stąd trzeba zreformować społeczeństwo o tyle, o ile pozwala ludzka natura, w oczekiwaniu na świat, który nadejdzie. Widać to

98 S. Rutherford, A free disputation, s. 309.

99 G. Murdock, Beyond Calvin. The Intellectual, Political and Cultural World of Europe's Reformed Churches, c. 1540-1620, New York 2004, s. 78.

100 D. Estrada, Calvinism versus Constantinism, s. 10. 
szczególnie na terenach rządzonych przez protestantów, gdzie miejscowe kościoły współpracowały z władzą świecką, by narzucić moralną dyscyplinę, odwołując się do „miecza publicznego" - w Szkocji podstawą takiego systemu stała się Book of Discipline Knoxa, wzorowana na rozwiązaniach genewskich. W identycznym duchu wypowiada się Rutherford, dla którego celem wysiłków państwa i Kościoła jest oddziaływanie na upadłą ludzką naturę drogą nakazów i represji. Celem polityki jest bowiem przygotowanie miejsca nowemu królestwu, poprawa świata, w którym człowiek byłby pobożny i sprawiedliwy. Z tego powodu właśnie władca musi „wywrzeć zemstę za bluźnierstwo, bałwochwalstwo, jawną niewiarę"101. Ma to jednak czysto doczesny charakter, albowiem heretyków karze nie tyle za herezję, ile za naruszenie ładu publicznego, ,ponieważ jest zła i niszcząca dla ludzkiego społeczeństwa, którego urzędnik przez swój urząd powinien bronić"102. Nie czyni tego więc jako zwierzchnik Kościoła, lecz jako jego obrońca i obrońca pokoju publicznego, a zatem przede wszystkim w ziemskim, a nie duchowym wymiarze. Oddziałuje jedynie na zewnętrzne zachowania człowieka, kwestie sumienia leżą bowiem poza jego jurysdykcją i oddziaływaniem, ponieważ „ani Kościół, ani Państwo nie mogą osądzić tkwiących w sercu przekonań, ani ukarać ich, lecz karzą jedynie jawne i rozpowszechniane opinie, które są zarówno niepotrzebne, jak i niezdrowe"103. Tak zatem jak władza nie można sprawić, by morderca i nikczemnik za sprawą kary stali się prawymi obywatelami, tak samo miecz nie zmusi heretyków i bałwochwalców do przyjęcia prawdziwej wiary. Tylko Bóg może otworzyć zatwardziałe serca, dlatego nawracać mogą duchowni, a narzędziem ku temu jest Słowo, a nie miecz, król zaś jedynie dba o jedność religijno-polityczną wspólnoty, wywierając zemstę na wichrzycielach lub usuwając ze wspólnoty zainfekowane herezją części. Jest tak, ponieważ

miecz nie sprawił kiedyś, ani nie sprawi teraz, by bałwochwalcy lub bluźniercy nawrócili się na prawdziwą wiarę, a broń proroków w Starym Testamencie i apostołów w Nowym była nie cielesna, lecz duchowa i potężna dzięki Bogu ${ }^{104}$.

Jednak i sam Kościół ma właściwe mu represyjne instrumenty perswazji i nacisku. Członkowie Kościoła mają być „,święci”, a ci, którzy są „,skandalicznie, nieświadomie, złośliwie, niezdrowi w wierze tracą swe prawa w wyborze urzędników i mają zostać wykluczeni od możliwości ich piastowania funkcji [kościelnych]"105. Tylko, jak pisze Rutherford, ,widoczne wyznawanie Prawdy i Doktryny wiary jest tym, co zasadniczo tworzy kościół i każdego członkiem widzialnego kościoła”106.

101 S. Rutherford, The due right of presbyteries, s. 395.

102 S. Rutherford, A free disputation, s. 187.

103 Ibidem, s. 315.

104 Ibidem, s. 190.

105 S. Rutherford, A survey of the Survey of that summe of church-discipline, J.G., London 1658 , s. 373.

106 S. Rutherford, The due right of presbyteries, s. 251. 
Musi być zatem utrzymana w nim dyscyplina, albowiem gdy jej zabraknie, „zmienia się w Babilon i jaskinię smoków"107.

\section{Rekapitulacja}

Analizując wywód Rutherforda, stwierdzić należy, że mimo iż jego doktryna ma w istocie formę teologii politycznej, której wszystkie elementy zachowują spójność tylko z chrześcijańskiej perspektywy, to bez wątpienia jest milowym krokiem ku sekularyzacji koncepcji państwa. Choć władza ostatecznie spoczywa w Bogu, to przyznanie ludowi prawa tworzenia i modyfikowania formy społeczeństwa politycznego nieuchronnie zmierza do wniosku, że w wymiarze technicznym źródłem władzy jest jednostka (lub lud). Późniejsze teorie kontraktowe są w istocie sekularyzacją kalwińskiej koncepcji przymierza rozwiniętej na kontynencie i za kanałem. Lecz choć kontraktualizm Hobbesa czy Locke'a wykazuje istotne (przynajmniej metodologicznie) podobieństwo do teologii politycznej teologów szkockiej reformacji, to brakuje mu elementu ich teologie konstytuującego. Nie mają bowiem boskiego elementu, który dla reformatorów był samym jądrem i fundamentem całej argumentacji. Jego zagubienie zaś czyni ideę kontraktu świecką i humanistyczną, a zatem całkowicie im obcą. Szczególnie dobrze widać to u Hobbesa, który będąc pod wpływem znanej mu doskonale teologii purytańskiej, sekularyzując ją, odbiera absolutną władzę Bogu, przekazuje ludziom, czyniąc z ich woli jedyny probierz dobra i zła, sprawiedliwości i niesprawiedliwości, a zatem tego, co dla Rutherforda dyskusji i konwencji nie podlega. Nie ma u niego kontraktu wertykalnego, a zatem nie ma też odpowiedzialności władzy przed Bogiem. Podobnie u Locke’a Bóg nie jest już stroną kontraktu, który choć zawierany jest dla samo zachowania, to dotyczy jedynie wymiaru horyzontalnego. Sama instytucja państwa również nie ma dla niego boskiej proweniencji, lecz czysto utylitarno-konwencjonalny charakter. Rutherford tymczasem twardo stoi na stanowisku, że choć konkretne państwa są dziełem ludzi, to sama instytucja nie została wymyślona przez człowieka, lecz dana im przez Boga, by podążać ścieżką wyznaczona przez Boskie przykazania. Bóg ciągle jednak pozostaje pierwszą przyczyną, oddając jedynie ludziom prawo określenia, w pewnych granicach, jego formy. Jednak u Locke'a to odrzucenie religijnego rygoryzmu pozwoliło na afirmację państwa, którego zasadą jest tolerancja. W konsekwencji zerwana zostaje szczególna relacja władzy ze Stwórcą, która nie ma już uniwersalnych i niezbędnych obowiązków wobec Niego, a musi jedynie polegać na niestabilnym i zmiennym poparciu ludzi. Odrzucając boskie prawo królów z jednej i wertykalny kontrakt Covenanters z drugiej strony, Locke pozbawia władzę instancji, do której mogłaby się w sytuacji kryzysu odwołać. Dlatego choć argument Rutherforda w wielu miejscach przypomina wywód

\footnotetext{
107 Ibidem, s. 288.
} 
Locke'a, to nie bez przyczyny ten ostatni woli odwoływać się do argumentu ,rozumnego Hookera", a nie autora Free disputation z jego nietolerancją i uzasadnieniem prześladowań. By oddać sprawiedliwość autorowi Lex, Rex, pamiętać należy o czasie i okolicznościach, w których tworzył, okolicznościach zasadniczo odmiennych od współczesnego, zdesakralizowanego świata. To, co dla Rutherforda było sensem wszystkich wysiłków, a zatem Republica Christiana prowadząca do Boga, nie ożywia już umysłów ani nie pobudza ludzkich działań. Tymczasem dla niego chrześcijański charakter wspólnoty politycznej i odpowiedzialność władzy wobec Boga były czymś oczywistym, a współczesne państwo, oparte częściowo na desakralizacji jego projektu, wydawałoby mu się nierzeczywiste i bluźniercze. Tak samo jednak jak bluźniercze i niedopuszczalne wydawały się nawoływania Rutherforda Miltonowi, który uczynił go jednym z bohaterów sonetu On the New Forcers of Conscience under the Long Parliament, atakującego przeciwników tolerancji i wolności sumienia:

\footnotetext{
Because you have thrown off your Prelate Lord, And with stiff Vows renounced his Liturgy

To seize the widowed whore Plurality

From them whose sin ye envied, not abhorred,

Dare ye for this adjure the Civil Sword

To force our Consciences that Christ set free,

And ride us with a classic Hierarchy

Taught ye by mere A. S. and Rutherford?

Men whose Life, Learning, Faith and pure intent

Would have been held in high esteem with R. Paul

Must now be named and printed Heretics

By shallow Edwards and Scotch what d'ye call:

But we do hope to find out all your tricks,

Your plots and packing worse then those of Trent,

That so the Parliament

May with their wholesome and preventive Shears

Clip your Phylacteries, though baulk your Ears,

And succor our just Fears,

When they shall read this clearly in your charge:

New Presbyter is but Old Priest writ Large.
}

\section{Bibliografia}

Bamberg S., A Footnote to the Political Theory of John Adams Vindiciae contra tyrannos, „Premise" 3, 1996, nr 7.

Bell M.Ch., Calvin and Scottish Theology. The Doctrine of Assurance, Edinburgh 1985.

The Booke of the Universall Kirk. Acts and Proceedings of the General Assemblies of the Kirk of Scotland, 1560-1618, Maitland Club, Edinburgh 1845.

Burrell S.A., The Covenant Idea as a Revolutionary Symbol: Scotland, 1596-1637, „Church History" 27, 1958.

Calvin J., Institutes of the Christian Religion, przeł. F.L. Battles, Louisville 1960. 
Campbell W.M., Lex, Rex and its Author, „Scottish Church History Society” 1941.

Chadwick O., The Reformation, Harmondsworth 1964.

Church, Politics and Society. Scotland 1408-1929, red. N. MacDougall, Edinburgh 1983.

Coffey J., The Impact of Apocalypticism during the Puritan Revolutions, „Perichoresis” 4, 2006, nr 2.

Coffey J., Politics, Religion and the British Revolutions. The Mind of Samuel Rutherford, Cambridge 1997.

Coffey J., Puritanism and Liberty Revisited: The Case for Toleration in the English Revolution, „The Historical Journal” 1998, nr 4.

The Covenant Connection. From Federal Theology to Modern Federalism, red. D.J. Elazar, J. Kincaid, Lanham 2000.

Elazar D.J., Covenant and Commonwealth. From Christian Separation through the Protestant Reformation. The Covenant Tradition in Politics, New Brunswick 1998.

Estrada D., Calvinism versus Constantinism, „Christianity \& Society” 14, 2004, nr 2.

Estrada D., Rutherford as a Presbyterian Theologian and Political Thinker, „Christianity \& Society" 13, 2003, $\mathrm{nr} 4$.

Flinn R., Samuel Rutherford and Puritan Political Theory, „Journal of Christian Reconstruction” 5, 1978-1979.

Freitas Sh. de, Raath A., Samuel Rutherford and the protection of religious freedom in early seventeenth-century Scotland, „Historical and Theological Studies” 78, 2016.

Gillespie G., A late dialogue betwixt a civilian and a divine concerning the present condition of the Church of England in which, among other particulars, these following are especially spoken of ..., Robert Bostock, London 1644.

Gough J.W., The Social Contract. A Critical Study of its Development, Oxford 1975.

Gribben C., Samuel Rutherford And Liberty of Conscience, „Westminster Theological Journal” $71,2009, \mathrm{nr} 2$.

Hetherington W.M., History of the Church of Scotland from the introduction of Christianity to the period of the disruption of 1843, Robert Carter \& Brothers, New York 1851.

Hetherington W.M., History of the Westminster Assembly of Divines, James Gemmell, Edinburgh 1878.

Hill Ch., The English Bible and the Seventeenth-Century Revolution, London 2014.

The Holy Bible, Baker, London 1611.

Junius Brutus, Vindiciae contra Tyrannos: A Defence of Liberty against Tyrants, or Of the lawful power of the Prince over the People, and of the People over the Prince, Richard Baldwin, London 1689.

Kelly D.F., The Emergence of Liberty in the Modern World. The Influence of Calvin on Five Governments from the 16th Through 18th Centuries, Philipsburg 1992.

Knox J., A Brief Exhortation to England, for the Speedy Embracing of the Gospel Heretofore by the Tyranny of Mary Suppressed and Banished 1559, Dallas 1995.

Knox J., History of the Reformation in Scotland, Blackie\&Son, Glasgow 1841.

Knox J., On Rebelion, Cambridge 1994.

Lecler J., Historia tolerancji w wieku reformacji, przeł. L. Kühn, Warszawa 1964.

Letham R., The Westminster Assembly. Reading its Theology in its Historical Context, Phillipsburg 2009.

The Letters and Journals of Robert Baillie, 1637-1662, Bannatyne Club, Edinburgh 1841.

Lockwood O'Donovan J., Political Authority and European Community: The Challenge of the Christian Political Tradition, „Scottish Journal of Theology” 47, 1994, nr 1.

Moots G.A., Politics Reformed. The Anglo-American Legacy of Covenant Theology, Columbia-London 2010.

Murdock G., Beyond Calvin. The Intellectual, Political and Cultural World of Europe's Reformed Churches, c. 1540-1620, New York 2004.

Studia nad Autorytaryzmem i Totalitaryzmem 41, nr 3, 2019

(C) for this edition by CNS 
Paul R., The Assembly of the Lord. Politics and Religion in the Westminster Assembly and the Grand Debate, Edinburgh 1985.

Puritans and Puritanism in Europe and America. A Comprehensive Encyclopedia, red. F.J. Bremer, T. Webster, Santa Barbara-Denver-Oxford 2006.

Rutherford S., The covenant of life opened, or, A treatise of the covenant of grace, Andro Anderson, Edinburgh 1655.

Rutherford S., The divine right of church-government and excommunication: or a peacable dispute for the perfection of the holy scripture in point of ceremonies and church government, John Field, London 1646.

Rutherford S., The due right of presbyteries, or, A peaceable plea for the government of the Church of Scotland, E. Griffin, London 1644.

Rutherford S., Fourteen communion sermons, Bonar, Glasgow 1877.

Rutherford S., A free disputation against pretended liberty of conscience tending to resolve doubts moved by Mr. John Goodwin, John Baptist, Dr. Jer. Taylor, the Belgick Arminians, Socinians, and other authors contending for lawlesse liberty, or licentious toleration of sects and heresies, Andrew Crook, London 1649.

Rutherford S., Letters, Co.Waterford, London 1857.

Rutherford S., Lex, Rex, or The Law and the Prince; A dispute for The Just Prerogative of King and People: containing The reasons and causes of the most necessary defensive wars of the Kingdom of Scotland, and of their Expedition for the aid and help of their dear brethren of England; in which their innocency is asserted, and a full answer is given to a seditious pamphlet, entitled, Sacro-Sancta Regnum Majestatis, Robert Ogle and Oliver \& Boyd, Edinburgh 1843.

Rutherford S., A peaceable and temperate plea for R. Pauls presbyterie in Scotland, or, A modest and brotherly dispute of the government of the Church of Scotland wherein our discipline is demonstrated to be the true apostolick way of divine truth, and the arguments on the contrary are friendly dissolved, the grounds of separation and the indepencie [sic] of particular congregations, in defence of ecclesiasticall presbyteries, synods, and assemblies, are examined and tryed, Iohn Bartlet, London 1642.

Rutherford S., Quaint Sermons, Hoddes and Stoughton, London 1885.

Rutherford S., A survey of the Survey of that summe of church-discipline, J.G., London 1658.

Salmon J.H.M., The French Religious Wars in English Political Thought, Oxford 1959.

Scots and Britons Scottish political thought and the union of 1603, red. R.A. Mason, Cambridge 1994.

The Scottish National Covenant in its British Context, red. J. Morrill, Edinburgh 1990.

Stevenson A., The History of the Church and State in Scotland from the Accession of King Charles I to the Year 1625. To which is Prefixed an Abstract of the State of Religion in Scotland, from the Earliest Acts of Christianity, to the Year 1625, Andrew Jack, Edinburgh 1844.

Toon P., Puritans and Calvinism, Swengel 1973.

Wielomski A., Myśl polityczna reformacji i kontrreformacji, Radzymin 2013.

\section{FROM THE CONTRACT OF GOVERNMENT TO RELIGIOUS INTOLERANCE. SAMUEL RUHTERFORD AND CONTRACTARIAN JUSTIFICATION OF RELIGIOUS PERSECUTIONS}

\section{Summary}

Samuel Rutherford (1600?-1661) was a Scottish Presbyterian minister whose political writings form a part of the controversial literature written during the English Civil War period in the mid-seventeenth century. Most of his political writing was done while he sat as a Scottish commissioner in the Westminster Assembly of Divines. His major political book, Lex, Rex was burned 
by order of the Restoration Government in 1660, and Rutherford was cited on a charge of treason as its author. In his opinion, in order to form a government men contract with one or more men among themselves, giving to them the authority of rulership. The ruler is under contract to rule according to the higher law for the welfare of all people. Rulership is a trust from the people and is never given without reservation. If the ruler misuses his trust, the people have the right and duty to resist him in order to preserve themselves within the higher law. Knowledge of the higher law comes through reason but reason is fallible. However, God has graciously provided the infallible Scripture as a guide to reason. Rutherford believes there is only one true interpretation of Scripture and that God has given to the Church primary authority in interpretation. In this article, the Author argues that Rutherford's doctrine of exclusive truth leads him to an uncompromising position of religious intolerance.

Keywords: Rutherford, Puritan Revolution, social contract, intolerance.

Tomasz Tulejski

ttulejski@tlen.pl 